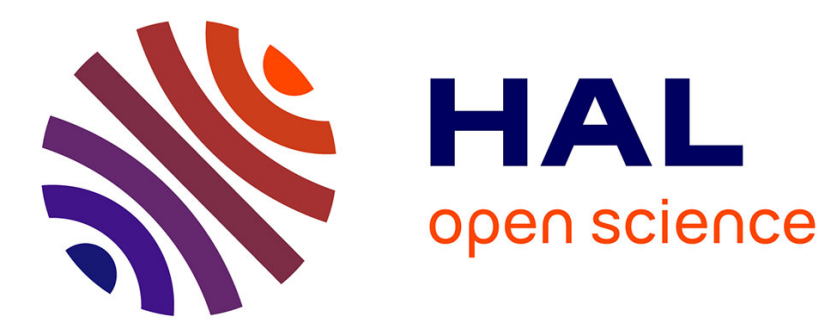

\title{
Grafting of Chemical Groups onto Polymers by Means of RF Plasma Treatments : a Technology for Biomedical Applications
}

\author{
P. Favia, R. d'Agostino, F. Palumbo
}

\section{- To cite this version:}

P. Favia, R. d'Agostino, F. Palumbo. Grafting of Chemical Groups onto Polymers by Means of RF Plasma Treatments : a Technology for Biomedical Applications. Journal de Physique IV Proceedings, 1997, 07 (C4), pp.C4-199-C4-208. 10.1051/jp4:1997415 . jpa-00255571

\section{HAL Id: jpa-00255571 \\ https://hal.science/jpa-00255571}

Submitted on 1 Jan 1997

HAL is a multi-disciplinary open access archive for the deposit and dissemination of scientific research documents, whether they are published or not. The documents may come from teaching and research institutions in France or abroad, or from public or private research centers.
L'archive ouverte pluridisciplinaire HAL, est destinée au dépôt et à la diffusion de documents scientifiques de niveau recherche, publiés ou non, émanant des établissements d'enseignement et de recherche français ou étrangers, des laboratoires publics ou privés. 


\title{
Grafting of Chemical Groups onto Polymers by Means of RF Plasma Treatments: a Technology for Biomedical Applications
}

\author{
P. Favia, R. d'Agostino and F. Palumbo \\ Dipartimento di Chimica, Università di Bari, Centro di Studio per la Chimica dei Plasmi, CNR, \\ via Orabona 4, 70126 Bari, Italy
}

\begin{abstract}
A brief review on plasma-processes used in biomedical applications is presented, along with results obtained by our group on the plasma-grafting of chemical functionalities onto polymers. RF Glow Discharges in $\mathrm{NH}_{3} / \mathrm{H}_{2}$ and $\mathrm{O}_{2} / \mathrm{H}_{2} \mathrm{O} / \mathrm{H}_{2}$ feeds have been utilized for grafting nitrogen-(e.g. $\left.-\mathrm{NH}_{2}\right)$ and oxygen-containing $(e . g .-\mathrm{OH},-\mathrm{COOH})$ functionalities onto polymers in a reproducible, controlled, selective fashion. Efficiency and selectivity of the grafting can, in principle, be tuned by optimizing the treatments with a proper, combined use of Actinometry and derivatization-aided Electron Spectroscopy for Chemical Analysis. Grafted - $\mathrm{COOH}$ groups have been used as "anchor sites" for immobilizing heparin and highly-sulphated hyaluronic acid in an active, anti-thrombotic form onto polyethylene.
\end{abstract}

\section{INTRODUCTION}

According to many reviews [1-4], low-pressure, non-equilibrium plasma-processes allow to alter the surface of polymeric biomaterials (see refs. [5-8] for proper definitions of the words biomaterial and biocompatibility ) in a number of attractive ways for improving their compatibility with blood, soft tissues, bones, cells and biomolecules in biomedical applications.

Plasma Enhanced Chemical Vapor Deposition (PE-CVD) and Plasma Treatments (PT) are the favourite plasma-techniques for changing surface properties such as wettability, lubricity, adhesion to other materials, cell growth, leach of additives and protein adsorption in biomedical devices. Vascular grafts, heart valves, catheters and other devices used in contact with human blood, for example, can take advantage of blood-compatible plasma-deposited coatings [2,9-11] as well as of anti-thrombotic molecules immobilized onto plasma-treated surfaces $[1,7,12-16]$. Plasma Treatments, i.e. plasma-processes performed with non-depositing reactive $\left(\mathrm{NH}_{3}, \mathrm{O}_{2}, \mathrm{~N}_{2}\right.$, etc.) or inert (Ar, He) gas feeds, are used for altering only the topmost layer of a polymer surface by grafting chemical functionalities and/or by crosslinking the polymer chains through positive-ion bombardment. Radio Frequency (RF, $13.56 \mathrm{MHz}$ ) Glow Discharges are the most popular plasma sources for PE-CVD and PT processes. 
Table 1 lists classes of surfaces that can be engineered on biomedical devices and prostheses by means of PE-CVD and PT. This contribution is designed to show how Plasma Treatments can be driven for grafting, somewhat in a selective fashion, chemical polar groups onto the surface of polymers, and how Actinometry [17-19] and Electron Spectroscopy for Chemical Analysis can be utilized for investigating the process. This approach can be utilized for engineering polymer surfaces with a dosed density of proper functionalities to be utilized for immobilizing biomolecules onto polymers.

TABLE 1. Deliverables of PE-CVD and PT

processes of interest in biomedical applications

\author{
Blood-compatible surfaces \\ PE-CVD of coatings with blood-compatible properties. \\ Anti-thrombotic biomolecules immobilized onto plasma-treated polymers. \\ Non-fouling surfaces \\ PE-CVD of coatings where proteins, cells, bacteria, biofilms, etc. don't adhere. \\ Surfaces with taylored hydrophilic-hydrophobic character \\ PE-CVD of coatings with taylored surface energy. \\ Grafting of polar (e.g. - $\mathrm{OH},-\mathrm{COOH}, \mathrm{N}$-groups) or non polar (e.g. - F, - $\mathrm{CF}_{\mathrm{x}}$ ) \\ functionalities by means of Plasma Treatments. \\ Sterilization and cleaning \\ Plasma Treatments with oxidizing $\left(e . g . \mathrm{O}_{2}\right)$ ashing feeds. \\ Barrier coatings \\ PE-CVD of barrier coatings for: drug-release systems, gas-exchange membranes, \\ device protection, reduction of leaches (ions, additives, catalyst) from materials.
}

\title{
2. ON THE USE OF DIAGNOSTIC TECHNIQUES IN THE BIOMATERIAL FIELD
}

Process control is usually performed in the biomaterial community at the end of the plasma-process, by means of surface analysis techniques such as: Electron Spectroscopy for Chemical Analysis (ESCA), static Secondary Ion Mass Spectroscopy (s-SIMS), Scanning Electron Microscopy (SEM), Attenuated Total Reflectance FTIR (ATR-FTIR) spectroscopy and Contact Angle (CA) measurements [20, 21]. Recently, ESCA analysis of hydrated-frozen surfaces has been developed $[22,23]$ and derivatization techniques introduced [24] for investigating in deeper detail polymer surfaces of biological interest. More advanced techniques such as Near Edge X-ray Absorption Fine Structure (NEXAFS) [25, 26] and scanning probe methods such as Atomic Force Microscopy (AFM) [27] have been utilized too.

The great attention dedicated to the study of plasma-processed surfaces, as well as to the interactions of such surfaces with blood, tissues, cells, proteins and other biological systems, is not counterbalanced, in the field of biomaterials, by the diagnostic analysis of what happens in the plasma gas-phase; further, low to none care is payed to reactor engineering and very simple reactor configurations are used. The density of the active species in the plasma, the bias of the surfaces and other internal parameters $[19,28-31]$ that, at 
the end, drive surface modifications at a chemical level in glow discharges, apparently are not a concern in the biomaterial community, as it comes evident from the literature of the field. This lack of process control, common also for applications in other areas (food packaging, corrosion protection, etc.) where nonequilibrium plasmas are used, is responsible of a trial-and-error, black box approach to plasma-processing, which has contributed to generate problems of reproducibility and difficulties of technological transfers and scale-up of processes. Process control is possible, instead, because well established reactor-engineering criteria and a large number of plasma-diagnostic techniques [17-19, 28, 29, 32-34] are available from the scientific background of microelectronics. Plasma diagnostics such as Optical Emission Spectroscopy (OES), Laser Induced Fluorescence (LIF), Mass Spectrometry (MS), Langmuir Electrostatic Probes (LEP), IR and UV Adsorption Spectroscopy (IR-AS, UV-AS), particularly when applied in situ and supported by surface analysis, have contributed to fully understand, optimize and control at submicron level plasma-etching and PE-CVD processes devoted to the production of highly integrated electronic circuits. This approach has led to the booming development of the microelectronic technology led by plasma-processes.

This picture of the situation reflects the point of view of the authors. We are convinced that coupling surface and plasma diagnostic techniques would allow to fully exploit plasma-processes also in biomaterial science, where their potential as surface modification techniques is already recognized and appreciated, but only partially exploited.

\section{GRAFTING OF CHEMICAL FUNCTIONALITIES ONTO POLYMERS BY MEANS OF PLASMA TREATMENTS}

Plasma Treatments can graft proper chemical groups onto polymers and consequently increase (e.g. with $\mathrm{NH}_{3}, \mathrm{O}_{2}, \mathrm{~N}_{2}$ plasma feeds) or lower (e.g. with $\mathrm{CF}_{4}$ ) their surface energy and hydrophilic-hydrophobic character, two related properties that drive the interactions with biological systems. Plasma-grafting oxygen- or nitrogen-containing polar groups, as an example, can improve adhesion and growth of cells on polymers $[1-3,35,36]$ utilized in prostheses and biomedical devices, while plasma-fluorination can work in the opposite way [37].

Selected plasma-grafted chemical functionalities such as $-\mathrm{NH}_{2},-\mathrm{OH},-\mathrm{COOH}$ are also utilized as anchor sites for covalently immobilizing biomolecules able to confer their biological properties (molecule recognition, anti-thrombogenicity and blood-compatibility, wear resistance, non fouling character) to the surface where they are tied $[1,7,38]$. Immobilization procedures always start with plasma-processing of the polymer substrate, then continue with wet reactions. A spacer molecule with proper functional groups on both ends is immobilized on the grafted surface with one side, then bound to the biomolecule on the other side. The spacer can be essential for ensuring to the biomolecule full conformational movement, thus biological activity; direct coupling to polymer surfaces, in fact, can lead to inactivation and denaturation $[39,40]$. Also PE-CVD can provide layers with proper functional groups. With this approach heparin has been immobilized onto materials such as polyethylene (PE), pyrolitic carbon and others [12-16], collegene has been immobilized onto polytetrafluoroethylene [41] and glucose oxidase (GOx) onto polyurethane [42]. 
Ageing of the plasma-treated surfaces (i.e. rearrangements, mobility of groups and polymer chains, reactions of groups with atmospheric oxygen, contaminations, loss of volatile or soluble compounds [35, $43,44])$ is always a concern for the applications, since the recovery of the surface properties (e.g. wettability) toward the values of the untreated surface usually happens with time. The shelf life of a plasma-treated surface should always be evaluated, and the timing of conventional processes to be applied on such surface carefully planned, in order to have each reaction (i.e. molecule immobilization) or procedure (i.e. cell growth, protein adhesion) to be lately practiced fully effective.

\subsection{Grafting of nitrogen-containing functionalities, with particular reference to $-\mathrm{NH}_{2}$}

Polymer substrates have been modified in a tubolar quartz reactor by means of $\mathrm{NH}_{3} / \mathrm{H}_{2}$ RF Glow Discharges. External parameters such as the $\mathrm{NH}_{3} / \mathrm{H}_{2}$ feed ratio and the $\mathrm{RF}$ power imput, that can be conveniently tuned for changing the distribution of species in the plasma, as well as the position of the substrate in the plasma reactor (glow vs . afterglow) and the treatment time have been changed, in order to explore their influence on the grafting process $[45,46]$.

ESCA analysis of treated polymers allows to measure their surface $N / C$ surface ratio, which has been taken as a measure of the efficiency of the treatment in grafting all kinds of N-groups. 4-trifluoromethylbenzaldehyde (TFMBA) vapors have been utilized for titrating $-\mathrm{NH}_{2}$ groups grafted onto $\mathrm{PE}$ and polystyrene in a well-characterized and selective derivatization procedure [45]. The fluorine density of the derivatized surfaces, proportional to the density of grafted $-\mathrm{NH}_{2}$ groups, allows to express the selectivity of the treatment $\left(\mathrm{NH}_{2} / \mathrm{N}\right.$ surface ratio) in grafting $-\mathrm{NH}_{2}$ rather than other $\mathrm{N}$-groups. Actinometric Optical Emission Spectroscopy (AOES), simply known as Actinometry, has been used for investigating the distribution of species formed in the discharges. It allows to monitor, in a semi-quantitative fashion, the relative density of emitting species in the plasma-phase as a function of external parameters such as pressure, feed gas composition and flow rate, power, etc., provided certain conditions are satisfied [17-19, 30]. He and Ar have to be added in small and constant quantity to the feed in order to compare their emission with those of the other emitting species. Table 2 shows the species detected in $\mathrm{NH}_{3} / \mathrm{H}_{2} \mathrm{RF}$ Glow Discharges, along with their spectral features.

TABLE 2. Emission lines and bands observed by AOES in $\mathrm{NH}_{3} / \mathrm{H}_{2}$ RF Glow Discharges

\begin{tabular}{lll}
\hline Species & System & Spectral feature $(\AA)$ \\
\hline $\mathrm{NH}$ & $\mathrm{A}^{3} \Pi-\mathrm{X}^{3} \mathrm{~S}^{-}$ & 3360 \\
& $\mathrm{C}^{1} \Pi-\mathrm{a}^{1} \Delta$ & 3240 \\
$\mathrm{~N} 2$ & $\mathrm{c}^{3} \Pi u-\mathrm{B}^{3} \Pi g$ & 3159 \\
$\mathrm{H}$ & $2 \mathrm{p}^{2} \mathrm{P}^{0} 3 / 2-3 \mathrm{~d}^{2} \mathrm{D}_{3 / 2}$ & $6563(\mathrm{H} \alpha)$ \\
$\mathrm{Ar}$ & $4 \mathrm{~s}^{1}[1 / 2]^{0}-4 \mathrm{p}^{1}[1 / 2]$ & 7503 \\
$\mathrm{He}$ & $2 \mathrm{~s}^{3} \mathrm{~S}-3 \mathrm{p}^{3} \mathrm{p}^{0}$ & 3889 \\
\hline
\end{tabular}


Correlating the relative density of the species detected by AOES with the efficiency and selectivity of the grafting performed in various conditions has allowed to draw the chemical mechanism of the process. Figure $1 \mathrm{~A}$ shows how the N/C surface ratio of treated PE correlates with the actinometric density of excited $\mathrm{N}_{2}, \mathrm{NH}$ and $\mathrm{H}$ species determined at different $\mathrm{H}_{2}$ feed content. The $\mathrm{N} / \mathrm{C}$ ratio increases with the relative density of the $\mathrm{N}$-species in the plasma-phase, while it is negatively correlated with that of $\mathrm{H}$-atoms. Opposite trends have been recorded as a function of the selectivity $\left(\mathrm{NH}_{2} / \mathrm{N}\right)$ of the process, as shown in figure 1B. Other species related to those mentioned above, e.g. $\mathrm{N}$ atoms, likely present in the plasma and involved in surface processes, have not been detected.
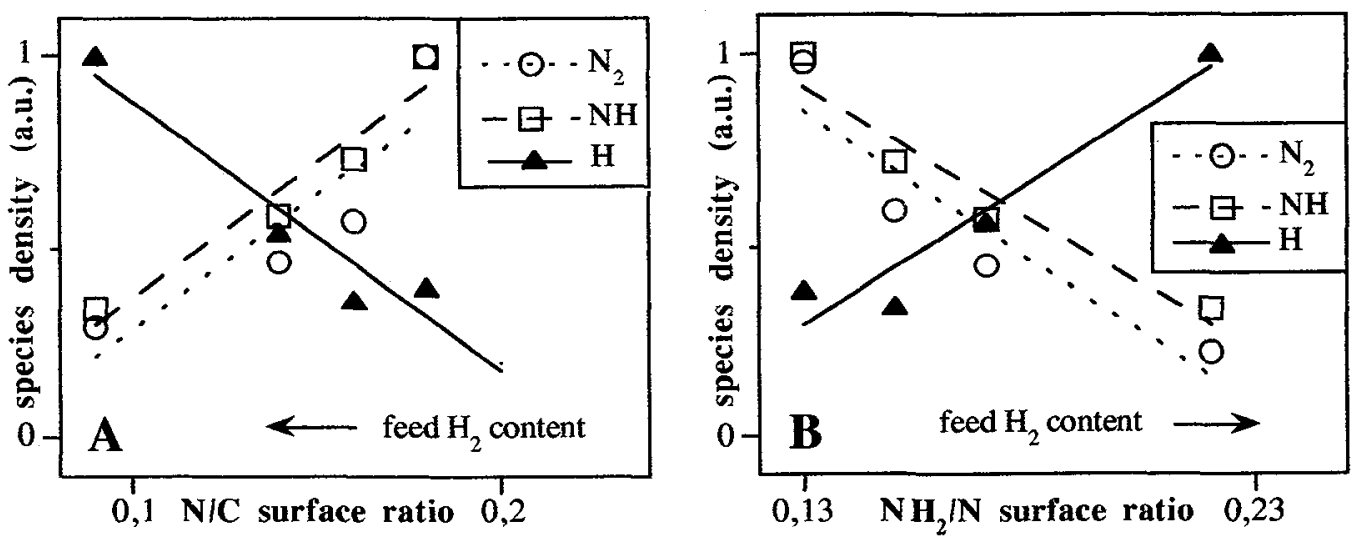

FIGURE 1. Relative species densities in RF Glow Discharges fed with different $\mathrm{NH}_{3} / \mathrm{H}_{2}$ flow ratios as a function of: $A$ ) the surface $\mathrm{N} / \mathrm{C}$ ratio $\mathrm{B}$ ) the surface $\mathrm{NH}_{2} / \mathrm{N}$ ratio of $\mathrm{PE}$ substrates directly exposed to the plasma (11 sccm total flow rate, glow position, $10 \mathrm{~W}, 500 \mathrm{mtorr}, 5 \mathrm{~min}$ ).

The correlations with the $\mathrm{N} / \mathrm{C}$ and $\mathrm{NH}_{2} / \mathrm{N}$ ratios holds also in other experimental conditions, and allow to elucidate the role of each class of species in plasma-surface interactions, as well as to identify the best conditions for obtaining a pre-determined surface chemistry. The chemical mechanisms of the treatment can be described as follows $[45,46]$ :

a - $\mathrm{NH}_{3}$ and $\mathrm{H}_{2}$ are fragmented in the glow and give origin to excited species, $\mathrm{NH}, \mathrm{N}_{2}$ and $\mathrm{H}$ among them, whose relative density can be tuned with the $\mathrm{NH}_{3} / \mathrm{H}_{2}$ feed ratio and the $\mathrm{RF}$ power.

b - Heterogeneous processes due to the $\mathrm{N}$-species graft $\mathrm{N}$-containing organic groups (e.g. amine, imine, cyano, etc.) at the surface of the polymer. The grafting process occurs, with different efficiency and selectivity, for substrates exposed directly to the plasma or placed in the afterglow zone of the reactor.

c - $\mathrm{H}$-atoms produce $-\mathrm{NH}_{2}$ groups on the polymer through the reduction of the other $\mathrm{N}$-functionalities. This role of the $\mathrm{H}$-atoms has been elucidated through afterglow and direct-glow $\mathrm{H}_{2}$ Plasma Treatments of substrates previously $\mathrm{NH}_{3}$ plasma-treated. The reduction process can be continued, in certain conditions, until no more nitrogen is detected on the nolvmer. 
Low $\mathrm{RF}$ power values, a low $\mathrm{H}_{2}$ (H-atoms) content in the feed and long ( $\geq 5 \mathrm{~min}$ ) treatment times allow to obtain high grafting N/C efficiency. On the other hand, high $\mathrm{RF}$ power values, a low $\mathrm{H}_{2}(\mathrm{H}-$ atoms) feed content, short (seconds) treatment times and, particularly, treatments with the substrate in the afterglow zone of the reactor, drive the process toward high $\mathrm{NH}_{2} / \mathrm{N}$ selectivity. Afterglow treatments show this effect most likely for the different life-times of the active species produced in the plasma, for their lower density respect to the glow zone and for the absence of positive-ion bombardment on the afterglow surfaces.

Efficiency and selectivity of $\mathrm{NH}_{3} / \mathrm{H}_{2}$ Plasma-Treatments follow always opposite trends as a function of the same parameter $[45,46]$; as a consequence, it is difficult to obtain surfaces characterized by an high absolute density of $-\mathrm{NH}_{2}$ groups in one step only. In order to bypass this situation and to test the effective ability of $\mathrm{H}$-atoms in reducing $\mathrm{N}$-groups to $-\mathrm{NH}_{2}$, different treatments in sequence have been experimented with success. A treatment in high grafting efficiency conditions is to be performed first, followed by a second one in the afterglow zone of an $\mathrm{H}_{2}$ discharge. The reduction of the $\mathrm{N}$-groups grafted in the first process takes place during the second, thus allowing high yields of $-\mathrm{NH}_{2}$ groups.

\subsection{Grafting of oxygen-containing functionalities, with particular reference to -COOH utilized for immobilizing heparin and highly-sulphated hyaluronic acid}

Heparin and highly-sulphated hyaluronic acid $\left(\operatorname{HyalS}_{\mathbf{x}}, \mathrm{x}=3.5\right)$ have been immobilized onto polyethylene previously plasma-grafted with oxygen-containing groups, $-\mathrm{COOH}$ among them [14, 47]. Heparin- and HyalS 3.5-immobilized samples show higher anti-coagulant character respect to the unmodified polymer. Due to its anti-thrombotic anticoagulant character, heparin is widely used in the treatment of cardiovascular deseases, surgery and extracorporeal blood circulation systems, and a large effort is being profused for obtaining heparin-like molecules like $\mathrm{HyalS}_{\mathrm{X}}$, as well as for immobilizing such molecules onto bloodcontacting devices.

PE substrates have been grafted with O-groups in a quartz tubolar reactor $[45,46]$ by means of RF Glow Discharges fed with $\mathrm{O}_{2} / \mathrm{H}_{2} \mathrm{O} / \mathrm{H}_{2}$ mixtures (Ar and He were added in small quantity for performing Actinometry [14]). Different RF power values, treatment times and the role of the position of the substrate (glow vs. afterglow) have been investigated. The species listed in Table 3 have been detected and their actinometric density profiles obtained as a function of the feed composition, as shown in Figure 2 for an $\mathrm{O}_{2} / \mathrm{H}_{2}$ discharge.

Differently from $\mathrm{NH}_{3}$-based plasmas, $\mathrm{O}_{2} / \mathrm{H}_{2} \mathrm{O} / \mathrm{H}_{2}$ discharges lead to the etching of organic polymers, as attested by $\mathrm{C}$-containing species $(\mathrm{CO}, \mathrm{CH})$ detected in the plasma. As a consequence, the formation of Low Molecular Weight Oxidized Materials (LMWOM) [48, 49] on the substrates has been noted. Such compounds form a weak, water-soluble boudary layer on the surface of the treated polymer, that makes difficult reproducing surface analysis.

ESCA analysis of PE treated in $\mathrm{O}_{2} / \mathrm{H}_{2} \mathrm{O} / \mathrm{H}_{2}$ RF Glow Discharges, then rinsed in distilled water and dried, has been performed, and the presence of $-\mathrm{COOH}$ groups available for the wet immobilization reactions attested on the final surface by means of derivatization with trifluoroethanol vapors according to $[14,24]$. Studies are in progress in our laboratory [50] aimed to find correlations between the relative 
density of the plasma species and the chemistry of the treated surface, similarly to those shown in 3.1. The scope of the investigation is to understand the chemical mechanism of the grafting-etching process, and to optimize plasma-parameters to the optimal density of $-\mathrm{COOH}$ groups needed for obtaining the best antithrobogenic surfaces.

TABLE 3. Emission lines and bands observed by $\mathrm{AOES}$ in $\mathrm{H}_{2} \mathrm{O} \mathrm{O}_{2} / \mathrm{H}_{2}$ RF Glow Discharges

\begin{tabular}{lll}
\hline Species & System & Spectral feature $(\AA)$ \\
\hline$C O^{*}$ & $\mathrm{~B}^{1} \Sigma-\mathrm{A}^{1} \Pi$ & $4511,4835,5198,5610$ \\
$\mathrm{OH}$ & $\mathrm{A}^{2} \Sigma^{+}-\mathrm{X}^{2} \Pi$ & 3064 \\
$\mathrm{CH}^{* *}$ & $\mathrm{~A}^{2} \Delta-\mathrm{X}^{2} \Pi$ & 4314 \\
$\mathrm{O}$ & $3 \mathrm{~s}^{3} \mathrm{~S}^{0}-3 \mathrm{p}^{3} \mathrm{P}$ & 8446 \\
$\mathrm{H}$ & $2 \mathrm{p}^{2} \mathrm{P}^{0} 3 / 2-3 \mathrm{~d}^{2} \mathrm{D}_{3 / 2}$ & $6563(\mathrm{H} \alpha)$ \\
$\mathrm{Ar}$ & $4 \mathrm{~s}^{1}[1 / 2]^{0}-4 \mathrm{p}^{1}[1 / 2]$ & 7503 \\
$\mathrm{He}$ & $2 \mathrm{~s}^{3} \mathrm{~S}-3 \mathrm{p}^{3} \mathrm{P}^{0}$ & 3889 \\
\hline
\end{tabular}

* Produced by the etching of the polymer substrate

** Produced by the etching of the polymer substrate when $\mathrm{H}_{2}$ is added to the feed

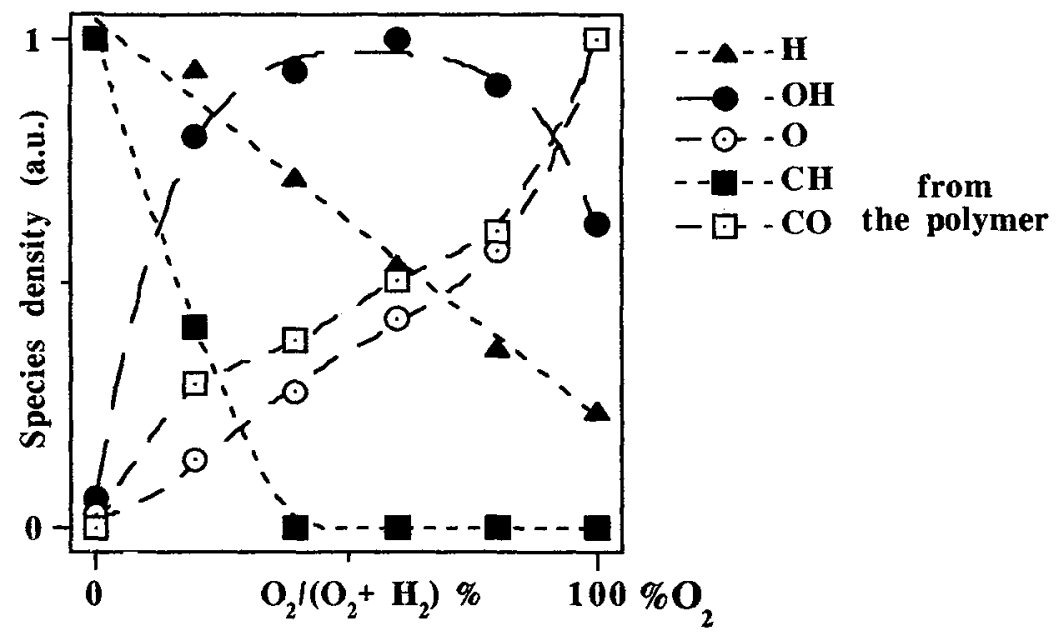

FIGURE 2. Relative species densities in RF Glow Discharges fed with different $\mathrm{O}_{2} / \mathrm{H}_{2}$ flow ratios as a function of the $\mathrm{O}_{2}$ percent in the feed. PE substrates are directly exposed to the plasma (11 sccm total flow rate, glow position, $10 \mathrm{~W}, 500 \mathrm{mtorr}, 5 \mathrm{~min})$.

O,O' bis (2-aminopropyl)polyethyleneglycol 500 (Fluka, avgd. m.w. 600 a.u., $\mathrm{n}=9-11, \mathrm{PEG}_{500}$ ) has been utilized as spacer-arm molecule to immobilize heparin (Roche) and HyalS 3.5 (synthesized from 
hyaluronic acid [511) onto plasma-modified PE. The detailed procedure, adapted from the literature [15] is reported elsewhere $[14,47]$. Each immobilization step, i.e. the immobilization of the spacer and that of the biomolecule, deals with the formation of amide covalent bonds between - $\mathrm{COOH}$ groups, grafted on PE and present on the biomolecules, and - $\mathrm{NH}_{2}$ functionalities present on both side of PEG500.

After each reaction step the substrates have been rinsed with deionized water and the presence of either the diamine spacer or that of heparin (or HyalS 3.5 ) revealed on the surface by detecting $\mathrm{N}$ and $\mathrm{S}$ atoms with ESCA, respectively. Both heparin and $\mathrm{HyalS}_{3.5}$, in fact, contain sulphur. Derivatization with TFMBA has been utilized for tracking the $-\mathrm{NH}_{2}$ groups of the immobilized PEG500 molecule on the substrates, thus confirming its presence for the next immobilization step. Best-fitting procedures of the N1s signals have been utilized in order to evaluate that PEG500 and other diamines utilized in the experiments were coupled to the surface by one amine side only, thus leaving the other available to react.

At the end of the modification steps heparin- and HyalS 3.5 -immobilized PE samples have been obtained, whose surface structure could be represented as in Figure 3. Blood-contact (thrombin time) and platelet-activation tests reveal for such samples an higher surface anti-coagulant character respect to unmodified PE, hence attesting that heparin and Hyal $\mathrm{S}_{3.5}$ have been immobilized in active form.

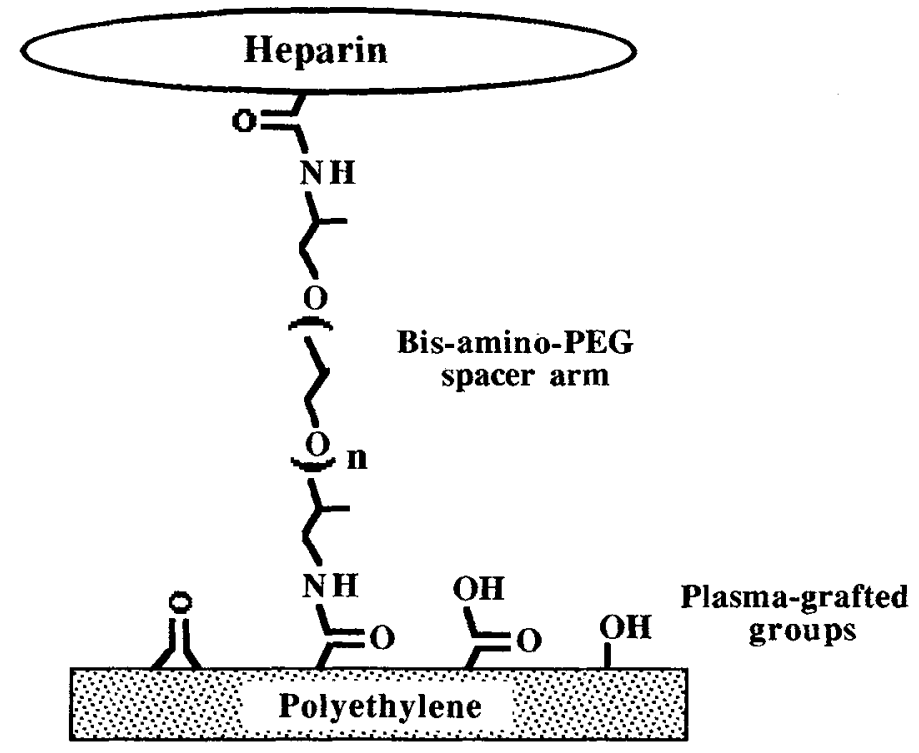

FIGURE 3. Sketch of heparin immobilized onto polyethylene by means of our procedure.

\section{Acknowledgements}

Prof. Rolando Barbucci, Dr. Agnese Magnani and Dr. Stefania Lamponi (Department of Science and Chemical Technologies of Biosystems, University of Siena, Italy) are gratefully acknowledged for providing heparin and $\mathrm{HyalS}_{3.5}$ molecules, as well as for important issues triggered by discussions and suggestions. 


\section{REFERENCES}

1 Gombotz W.R., Hoffman A.S., CRC Crit. Rev. Biocomp. 4(1) (1987) 1-42.

2 Ratner B.D., Chilkoti A., Lopez G.P. in: Plasma Deposition, Treatment and Etching of Polymers, d'Agostino R. ed., Plasma-Materials Interaction serie, Academic Press (1990) 463-516.

3 Ratner B.D. in: Plasma-Processing of Polymers, d'Agostino R., Favia P., Fracassi F. eds., Kluwer (1997), in press.

4 Yasuda H., Gazicki. M., Biomaterials 3(2) (1982) 68-77.

5 Williams D.F. ed., Progress in Biomedical Engineering 4 (1987).

6 Peppas N.A., Langer R., Science 263 (1994) 1715-1720.

7 Ratner B.D., Hoffman A.S., Lemons J.E., Schoen F.J. eds., Biomaterials Science - An introduction to materials in Medicine, Academic Press, New York, (1996).

8 Williams D.F., J. Mater. Sci. 22 (1987) 3421-3445.

9 Kiaei D., Hoffman A.S., Ratner B.D., Horbett A.T., Reynolds L.O., J. Appl. Pol. Sci.: Polym. Symp. 42 (1988) 269-283.

10 Garfinkle A.M., Hoffman A.S., Ratner B.D., Reynolds L.O., Hanson S.R, Trans. Am. Soc. Art. Int. Org. 30 (1984) 432-439.

11 Kiaei D., Hoffman A.S., Horbett A.T., J. Biomat. Sci.: Polym. Ed. 4 (1992) 35-44.

12 Yuan S., Cai W., Szakalas-Gratzl G., Marchant K.K., Tweden K., Marchant R.E., J. Appl. Biomat. 6 (1995) 259-266.

13 Yuan S., Szakalas-Gratzl G., Ziats N.P., Jacobsen D.W., Marchant K.K., Marchant R.E., J. Biomed. Mat. Res. 27 (1993) 811-819.

14 Favia P., Palumbo F., d'Agostino R., Lamponi S., Magnani A., Barbucci R., submitted.

$15 \quad$ Kyu Kang 1., Hyeong Kwon O., Moo Lee Y., Kiel Sung Y., Biomaterials 17 (1996) 841-847.

16 Pallassana V.N., J. Biomat. Sci. Pol. Ed. 6(2),(1994) 181-193.

17 Coburn J.W., Chen M.J., App. Phys. 51 (1980) 3134-3136.

18 d'Agostino R., Cramarossa F., De Benedictis S., Ferraro G., J. Appl. Phys. 52 (1981) 1259-1265.

19 d'Agostino R., Cramarossa F., Fracassi F., Illuzzi F. in: Plasma Deposition, Treatment and Etching of Polymers, d'Agostino R. ed., Plasma-Materials Interaction serie, Academic Press (1990) 95-162.

Ratner B.D. in: Plasma-Processing of Polymers, d'Agostino R., Favia P., Fracassi F. eds., Kluwer (1997), in press.

Ratner B.D., Cardiovase. Pathol. 2(3) supp. (1993) 87S-100S.

22 Ratner B.D., Castner D.G., Coll. Int. B; Bioint. 2 (1994) 333-346

23 Yasuda H., Charlson E.J., Charlson E.M., Yasuda T., Miyama M., Okuno T., Langmuir 7 (10) (1991) $2394-2400$.

24 Chilkoti A., Ratner B.D. in: Surface Characterization of Advanced Polymers, Sabbatini L., Zambonin P.G. eds., VCH (1993).

25 Castner D.G., Lewis Jr. K.B., Fischer D.A., Ratner B.D., Gland J.L., Langmuir 9 (1993) 537-542.

26 Castner D.G., Favia P., Ratner B.D. in: Surface Modifications of Polymeric Biomaterials, Castner D.G., Ratner B.D. eds., Plenum Press, New York (1996).

Klemberg-Sapieha J. in: Plasma-Processing of Polymers, d'Agostino R., Favia P., Fracassi F. eds., Kluwer (1997), in press.

28 Morosoff N. in: Plasma Deposition, Treatment and Etching of Polymers, d'Agostino R. ed., Plasma-Materials Interaction serie, Academic Press (1990) 1-93.

29 Kay E., Coburn J.W., Dilks A. in: Topics in Current Chemistry 94, Veprek S., Venugopalan M. eds., Springer Verlag, Berlin, (1980) 1. d'Agostino R. in: Plasma-Processing of Polymers, d'Agostino R., Favia P., Fracassi F. eds., Kluwer (1997), in press.

31 Favia P. in: Plasma-Processing of Polymers, d'Agostino R., Favia P., Fracassi F. eds., Kluwer (1997), in press.

32 Donnelly V.M. in: Plasma Diagnostics 1, Auciello O., Flamm D.L. eds., Academic Press, New York (1989) 1-46. 
33 Hershkowitz N. in: Plasma Diagnostics 1, Auciello O., Flamm D.L. eds., Academic Press, New York (1989) $113-183$.

34 Dreyfus R.W., Jasinski J.M., Walkup R.E., Selwyn G.S., Pure \& Appl. Chem. 57(9) (1985) 1265-1276.

35 Griesser H.J., Chatelier R.C., Gegenbach T.R., Johnson G., Steele J.G., J. Biomat. Sci. Pol. Ed. 5 (6) (1994) 531-554.

36 Lee J.H., Park J.W., Lee H.B., Biomaterials 12 (1991) 443-448.

37 Eloy R., Parrat D., Duc M.T., Legeay D., Bechetoille A., J. Cataract Ref. Surg. 19 (1993) $364-370$.

38 Hoffman A.S., Clin. Mat. 11 (1992) 61-66.

39 Kiaei D., Hoffman A.S., Horbett T.A., Lew K.R., J. Biomed. Mat. Res. 29 (1995) 729-739.

40 Safranj A., Kiaei D., Hoffman A., Biotechnol. Prog. 7 (1991) 173-177.

41 Tran N.B.C., Walt D.R., J. Coll. Int. 132(2) (1989) 373-381.

42 Danilich M.J., Marchant K.K., Anderson J.M., Marchant R.E., J. Biomat. Sci. PoL Ed. 3(3) (19912) $195-216$.

43 Xie X., Gegenbach T.R., Griesser H.J., J. Adh. Sci. Tech. 6(12) (1992) 1411-1431.

44 Youxian D., Griesser HJ., Mau A.W.H., Schmidt R., Liesegang J., Polymer 32(6) (1991) $1126-1130$.

45 Fuvia P., Stendardo M.V, d'Agostino R., Plasmas and Polymers 1 (2) (1996) 91-112.

46 Favia P., Palumbo F., Stendardo M.V, d'Agostino R. in: Surface Modifications of Polymeric Biomaterials, Castner D.G., Ratner B.D. eds., Plenum Press, New York (1996).

47 Favia P., Palumbo F., d'Agostino R., 213th ACS National Meeting, S. Francisco, USA, April 1997, Polymer Preprints 38(1) (1997) 1039-1040.

48 Foerch R., Beamson G., Briggs D., Surf. Int. Anal. 17 (1991) 842-846.

49 Wertheimer M.R., Bartnikas R. in: Plasma-Processing of Polymers, d'Agostino R., Favia P., Fracassi F. eds., Kluwer (1997), in press.

50 Palumbo F., Rinaldi A., Favia P., d'Agostino R., unpublished results.

51 Barbucci R., Magnani A., G. Cialdi G., Italian Patent PD 94 A000054. 